\title{
The Impact of Training Methods with Resistance Band Ladder Drills Training Pattern to Increase Physiological Ability of Female Futsal Players
}

\author{
Dikdik Zafar Sidik*, Asep Sumpena, Fitri Rosdiana \\ Department of Coaching Education \\ Universitas Pendidikan Indonesia \\ Bandung, Indonesia \\ *dikdikzafarsidik@upi.edu, asep_sumpena@upi.edu, fitrirosdiana@upi.edu
}

\begin{abstract}
This research aims to investigate the impact of interval and pyramid training methods with resistance band ladder drills training to increase the physiological ability of female futsal players, including dynamic aerobic and anaerobic abilities, which consists of endurance, strength, speed, agility, power, and power endurance. This research is an experimental research. The subjects of the research were selected using nonprobability technique from purposive sampling. The research instruments were in the form of Aerobic Ability and Anaerobic Ability Tests. The data analysis technique used for normality and T-tests with a significance level of 5\% was SPSS software. This research showed that there was a significant effect between the initial test results and the final test results with the interval training method in increasing aerobic ability, but it did not significantly influence anaerobic abilities. The pyramid training method to increase aerobic and anaerobic abilities also did not significantly influence the female futsal players. The implication of the research showed that in physical training, the training method must adapt to various elements of the physical component to be trained in accordance with the principles and norms of training in physiological and pedagogical laws in order to obtain the maximum meaningful impact of training.
\end{abstract} band

Keywords: aerobic, anaerobic, futsal, ladder drills, resistance

\section{INTRODUCTION}

The physiological role in physical training on the athletes' achievements nowadays is very visible. Indeed, it is due to the higher level of competition hence the demands for training needs are also higher. To complement the reference to the development of the achievements supported by science in coaching sports, physiologists along with sports practitioners (coaches) are motivated to make changes in applying more comprehensive interdisciplinary studies of science. It is supported by the increasing number of scientific studies on the results of physical training through the application of training methods and forms or models of the training. The development of scientific studies is still considered lacking in Indonesia, thus that the nation's sporting achievements are increasingly less encouraging. It can be seen from the results of the achievements from Sea Games to Sea Games in last fourteen years [1].

\begin{tabular}{|c|c|c|c|c|c|c|c|c|}
\hline & 2003 & 2005 & 2007 & 2009 & 2011 & 2013 & 2015 & 2017 \\
\hline Filipina & 4 & 1 & 6 & 5 & 6 & 7 & 6 & 6 \\
\hline Indonesia & 3 & 5 & 4 & 3 & 1 & 4 & 5 & 5 \\
\hline 些 Malaysia & 5 & 4 & 2 & 4 & 4 & 5 & 4 & 1 \\
\hline ॠ Myanmar & 7 & 7 & 7 & 8 & 7 & 2 & 7 & 7 \\
\hline Singapura & 6 & 6 & 5 & 6 & 5 & 6 & 2 & 4 \\
\hline E Thailand & 2 & 2 & 1 & 1 & 2 & 1 & 1 & 2 \\
\hline Vietnam & 1 & 3 & 3 & 2 & 3 & 3 & 3 & 3 \\
\hline
\end{tabular}

Fig. 1. Ranking list of state achievements in multi-event Sea Games.

Looking at the condition of Indonesia's achievements in multi-events in the table above, it is very concerning when it is compared to the total of population and the conditions of the past performance. During 2003 to 2017 , Indonesia was in the first place only when it became as a host. Whereas, Indonesia was always in the third place in 2003 and 2009. When it was compared to the six countries that had occupied the top three in Southeast Asia, Indonesia was in the fourth place for twice (2007 and 2013). While in 2005, 2015 and 2017 Indonesia was in the fifth place [1].

There are five physical components in sports that affect the achievement, namely speed, flexibility, skills, endurance, and strength. Each elite athlete develops each component as the part of the athlete's preparation to enter a competition. Speed and acceleration are the important qualities in the performance on the field, along with short-distance running speed as the fundamental ability to obtain the achievement [2].

The repetitive movement activities can cause fatigue in certain muscles during a match. Thus, it is important for players to practice strength [3]. Futsal is a sport that is dominant in terms of physical condition. It is in line with some literature which show that the physical demands of futsal becomes as an important consideration for coaches to implement training in participating in competitions [4-7]. These considerations include different physiologies among players at different levels of competition which can be seen from the needs of aerobic and anaerobic abilities in futsal. Then, how the energy system can be trained to improve 
maximum performance [6], and explore the aerobic fitness of futsal players at various competitive levels in order to determine whether aerobic fitness on futsal players is a discriminatory variable for success in futsal. Maximum oxygen absorption (VO2Max), Ventilatory Treshold (VT), and Running Economy (RE, VO2 at $8 \mathrm{~km}-\mathrm{h}-1)$ can be known between professional players and semi-professional players. The main finding of this research was that the level of aerobic fitness was significantly higher in professional players; it was highly trained than at low levels. Semi-professional players showed that aerobic fitness could be considered as a physical variable of a competitive level that depends on competitive levels in futsal, which also studies the demands of professional futsal matches. The researchers responded physiologically to activity patterns in playing futsal game simulations on professional players and found that futsal played at a professional level was a physical exercise that demands physical strengths consisting of aerobic and anaerobic abilities [8].

An analysis of movement demands in futsal has revealed that the players ran more than 4,500 meters during the match [9]. Therefore, futsal players really need endurance that is very supportive for their appearance. Futsal players do an average of nine training activities per minute in the game. Then, there is a high intensity effort every 23 seconds of the game which states that the average intensity of playing futsal usually results in 85$90 \%$ of the maximum heart rate (HRmax) and $75 \%$ of VO2Max [8].

Looking at the characteristics of futsal, it requires a high aerobic ability supported by good anaerobic abilities MILLET [10]. These research highlighted the importance of anaerobic and aerobic systems in futsal and their differences at various competitive levels, but other research also considered how this system could be developed through training to potentially improve the performance. A research of the impact of training on maximal intensity intervals based on skills on aerobic and anaerobic performance variables among female futsal players found that the average anaerobic power, fatigue index and Vo2max increased respectively $10.7 \%, 22.1 \%$ and $9.6 \%$. These are interesting findings, because they showed significant improvements which can provide evidence that players can improve their quality of competition by practicing this system [7].

Then, there is a limited time motion analysis of the futsal players during the match [6]. The pattern of futsal activity may be different from other sports because each player must be attacking and defending constantly with a high tempo [8]. This is understandable because futsal is a multi-sprint sport in which there is a phase of high intensity more than in other intermittent sports. Although comparing futsal with other sports has limitations, some useful comparisons can be made with similar intermittent team sports such as football, basketball and handball. For example, it has been shown that the total distance covered at high intensity and maximum speed is greater in futsal than in football [11,12], basketball [13], or handball [14], which reflects the high nature of futsal intensity. The work-torest ratio in futsal is around $1: 1$, which means that the rest means the player is stationary, walking or jogging, and work means the distance covered at medium, high or maximum speeds [4]. The intensity of futsal matches is proven to be higher than football. This is a direct consequence of the infinite reimbursement rules during futsal. Professional futsal players cover $13.7 \%$ of their total distance at high intensity (speed $\geq 15$ km.h-1) and $8.9 \%$ running (speed $\geq 25 \mathrm{~km} . \mathrm{h}-1$ ) [8], with players who do 8,6 activities per minute of the match [4]. Additionally, the players make a low intensity effort every fourteen seconds, a medium intensity effort every 37 seconds, a high intensity effort every 43 seconds, a maximum intensity effort every 56 seconds, and change the motion activity every 3.3 seconds [15]. From these findings, it can be concluded that futsal is an anaerobic multiple-sprint sport, which means that the high-intensity training is a greater proportion of match time than in soccer and other multiple-sprint sports.

Although the contribution during the game is high, the primary energy comes from anaerobic metabolism [4,6]. Physiologically, the current sports achievements consist of anaerobic and aerobic abilities. This is the ability that must be developed and improved by coaches, especially those who deal with athletes in their physical abilities. There are no athletes who only need one ability, either aerobic ability or anaerobic ability only. If you want to increase the aerobic ability, then you also need to increase the level of anaerobic ability, and vice versa.

The team with the best physical training can apply more tactics during the competition, while those with poor physical training can negatively affect the will of the athlete and jeopardize their learning ability and endurance during the training and competition. It has the potential to hamper the performance. Some research in this area ensure that there is a good basic evidence for further research [16]. Therefore, everything related to aerobic fitness in elite female futsal players becomes very attractive to coaches and sports scientists $[11,17]$.

In connection with the training patterns, this research used ladder drills. Ladder drills are an excellent form of training to increase speed, coordination, agility, and power. Agility ladder is a popular tool for speed, coordination, balance, and agility of people of various age groups, sports, and genders [18,19]. Ladder drill method is a method that matches the characteristics of futsal games that prioritizes speed and agility. The essence of agility training is that athletes are asked to run fast and turn fast without losing balance. Thus, it can be said that the agility training can also indirectly trains speed. A finding showed that there was an increase of agility after being given a ladder training exercise [20]. There was a significant effect of ladder drill training on running speed, agility, and leg power. Based on this research, only speed, agility and power, categorized as alactacid anaerobic abilities, were studied. While lactacid anaerobic ability and anaerobic dynamic ability had not been seen yet. In addition, there are limited research regarding the use of ladder drills training patterns [21]. Therefore, researchers were interested in using the ladder drills training pattern combined with a resistance band so that it is called as the resistance band ladder drills training pattern to improve physiological abilities in female futsal players and used two training methods; intervals and pyramids. 


\section{METHOD}

\section{A. Subjects}

The population and sample of this research were 20 female futsal athletes from UKM futsal Universitas Pendidikan Indonesia Puteri who were divided into two groups; ten athletes in the experimental group and ten athletes in the control group. After receiving a detailed description of the objectives, potential benefits, and risks associated with participating in this research, each student gave her written consent.

\section{B. Protocol}

In its implementation, the researchers conducted initial tests and measurements and then gave training treatments to the interval training method and the pyramid method. Then, the researchers conducted the final stages of testing and measurement. The steps in gathering the data were preparing test instruments and carrying out and measuring the test according to test procedures by some testers (four people who are experts in data collection). The data were collected in the form of quantitative data. The data collection schedule consisted of two stages; the first stage was the initial test to determine the initial conditions of the subject and the second stage was the final test to see the development of the results of the training treatment.

The method used in this research was experimental method with a Pretest-Posttest Control Group Design [22]. The research instruments used to carry out the process and collect data were in the form of resistance bands ladder drill training programs with interval training methods and pyramid training methods for 16 meetings and several test items to determine anaerobic and aerobic abilities. Aerobic ability was measured through the Bleep Test [23], while anaerobic ability was measured through a speed test in the form of a speed test $20 \mathrm{~m}$ dash sprint [24], speed in the form of agility was shuttle run $4 \mathrm{~m}$ x 5 rep [24], leg power was Single Leg Triple Hop for Distance Test [25], power endurance was Multi Stage Hurdle Jump Test [26] and speed endurance is $150 \mathrm{~m}$ sprint test [24].

\section{Statistical Analysis AND Results}

The data that had been obtained were then analysed using SPSS software. The analysis technique was paired sample ttest. This test was conducted to test whether there were any differences or influences.

In seeing the impact of the increase of the training method with resistance band ladder drills training pattern on physiological abilities, the first step was to test through normality testing using the Kolmogorov-Smirnov One-Sample Test. Then, because the distribution of subjects was normal, it continued with descriptive data testing using Paired Samples Statistics, followed by correlation test using Paired Samples Correlations.
TABLE I ONE SAMPLE KOLMOGOROV-SMIRNOV TEST OF EXPERIMENTAL GROUP WITH INTERVAL TRAINING METHOD FOR THE IMPROVEMENT OF AEROBIC ABILITY

\begin{tabular}{|c|c|l|}
\hline & & \multicolumn{1}{|c|}{ Gain } \\
\hline \multicolumn{2}{|c|}{$\mathbf{N}$} & 10 \\
\hline \multirow{2}{*}{$\begin{array}{c}\text { Normal } \\
\text { Parametersa }\end{array}$} & Mean & .8700 \\
\cline { 2 - 3 } $\begin{array}{c}\text { Most Extreme } \\
\text { Differences }\end{array}$ & Std. Deviation & 1.15667 \\
\cline { 2 - 3 } & Absolute & .192 \\
\cline { 2 - 3 } & Positive & .192 \\
\hline \multicolumn{2}{|c|}{ Negative } & -.136 \\
\hline \multicolumn{2}{|c|}{ Kolmogorov-Smirnov Z } & .608 \\
\hline \multicolumn{2}{|c|}{ Asymp. Sig. (2-tailed) } & .853 \\
\hline \multicolumn{2}{|c|}{ Test distribution is Normal } \\
\hline
\end{tabular}

Thus, the requirements or assumptions of normality in the use of paired sample T test have been fulfilled.

TABLE II. PAIRED SAMPLES STATISTICS OF EXPERIMENTAL GROUP WITH INTERVAL TRAINING METHOD FOR THE IMPROVEMENT OF AEROBIC ABILITY

\begin{tabular}{|l|l|l|l|l|}
\hline & Mean & N & $\begin{array}{c}\text { Std. } \\
\text { Deviation }\end{array}$ & $\begin{array}{c}\text { Std. } \\
\text { Error } \\
\text { Mean }\end{array}$ \\
\hline Pretest_Aerobic & 43.2700 & 10 & 1.78017 & .56294 \\
\hline Posttest_Aerobic & 44.1400 & 10 & 1.67677 & .53024 \\
\hline
\end{tabular}

From the table above, it can be seen that the average pretest score is 43.27 <post-test 44.14 , which means that there is the difference in the average of the exercise results between pre-test and post-test. To prove whether the differences are really significant (significant) or not, we need to interpret the results of the paired sample $\mathrm{T}$ test contained in the Paired Sample Test output table.

TABLE III. PAIRED SAMPLES CORRELATIONS OF EXPERIMENTAL GROUP WiTH INTERVAL TraINING METHOD IN INCREASING AEROBIC ABILITY

\begin{tabular}{|l|l|l|l|}
\hline & \multicolumn{1}{|c|}{ N } & $\begin{array}{c}\text { Correlatio } \\
\text { n }\end{array}$ & Sig. \\
\hline $\begin{array}{l}\text { Pretest_Aerobic \& } \\
\text { Posttest_Aerobic }\end{array}$ & 10 & .778 & .008 \\
\hline
\end{tabular}

The correlation coefficient value is 0.778 with a significance value is 0.008 . Looking at the value of Sig. 0.008 <probability 0.05 , it can be said that there is a relationship between pre-test and post-test variables.

TABLE IV. PAIRED SAMPLES Test OF EXPERIMENTAL GROUP WITH INTERVAL TRAINING METHOD FOR THE IMPROVEMENT OF AEROBIC ABILITY

\begin{tabular}{|c|c|c|c|c|c|c|c|c|}
\hline & \multicolumn{5}{|c|}{ Paired Differences } & \multirow[t]{3}{*}{$\mathbf{T}$} & \multirow{3}{*}{$\begin{array}{l}\mathbf{d} \\
\mathbf{f}\end{array}$} & \multirow{3}{*}{$\begin{array}{l}\text { Sig } \\
\dot{(2-} \\
\text { tail } \\
\text { ed) }\end{array}$} \\
\hline & \multirow[t]{2}{*}{$\begin{array}{l}\text { Me } \\
\text { an }\end{array}$} & \multirow[t]{2}{*}{$\begin{array}{c}\text { Std. } \\
\text { Dev } \\
\text { iati } \\
\text { on }\end{array}$} & \multirow[t]{2}{*}{$\begin{array}{l}\text { Std } \\
\cdot \\
\text { Err } \\
\text { or } \\
\text { Me } \\
\text { an }\end{array}$} & \multicolumn{2}{|c|}{$\begin{array}{c}95 \% \\
\text { Confidence } \\
\text { Interval of } \\
\text { the } \\
\text { Difference }\end{array}$} & & & \\
\hline & & & & $\begin{array}{c}\text { Low } \\
\text { er }\end{array}$ & $\begin{array}{l}\text { Up } \\
\text { per }\end{array}$ & & & \\
\hline $\begin{array}{l}\text { Pretest Aerobic - } \\
\text { Posttest Aerobic }\end{array}$ & $\begin{array}{l}-87 \\
00 \\
0\end{array}$ & $\begin{array}{l}1.15 \\
667\end{array}$ & $\begin{array}{l}.36 \\
577\end{array}$ & $\begin{array}{l} \\
1.69 \\
743\end{array}$ & $\begin{array}{l}- \\
.04 \\
257\end{array}$ & $\begin{array}{l} \\
2 . \\
37 \\
9\end{array}$ & 9 & $\begin{array}{l}.04 \\
1\end{array}$ \\
\hline
\end{tabular}


TABLE VIII. PAIRED SAMPLES Test OF EXPERIMENTAL GROUP With INTERVAL TRAINING METHOD FOR THE IMPROVEMENT OF ANAEROBIC ABILITY Sig value. (2-tailed) is $0.041<0.05$, then $\mathrm{H} 0$ is rejected and Ha is accepted. Therefore, it can be concluded that there is an average difference between pre-test and post-test. It means that there is an effect of interval training method with resistance band ladder drills training patterns in increasing aerobic abilities of female futsal players.

TABLE V. ONE SAMPLE KOLMOGOROV-SMIRNOV TEST OF EXPERIMENTAL GROUP WITH INTERVAL TRAINING METHOD FOR THE IMPROVEMENT OF ANAEROBIC ABILITY

\begin{tabular}{|c|c|l|}
\hline \multicolumn{2}{|c|}{$\mathbf{N}$} & Difference in \\
\hline \multirow{2}{*}{ Normal Parameters $^{\mathbf{a}}$} & Mean & 10 \\
\cline { 2 - 3 } & Std. Deviation & .0000 \\
\hline \multirow{2}{*}{$\begin{array}{c}\text { Most Extreme } \\
\text { Differences }\end{array}$} & Absolute & .30185 \\
\cline { 2 - 3 } & Positive & .119 \\
\cline { 2 - 3 } & Negative & -.119 \\
\hline \multicolumn{2}{|c|}{ Test distribution is Normal. } \\
\hline \multicolumn{2}{|c|}{ Kolmogorov-Smirnov Z } & .378 \\
\hline \multicolumn{2}{|c|}{ Asymp. Sig. (2-tailed) } & .999 \\
\hline
\end{tabular}

Thus, the requirements or assumptions of normality in the use of paired sample $\mathrm{T}$ test have been fulfilled.

TABLE VI. PAIRED SAMPLES STATISTICS OF EXPERIMENTAL GROUP WITH INTERVAL TRAINING METHOD FOR THE IMPROVEMENT OF ANAEROBIC ABILITY

\begin{tabular}{|l|l|l|l|l|}
\hline & Mean & N & $\begin{array}{c}\text { Std. } \\
\text { Deviation }\end{array}$ & $\begin{array}{c}\text { Std. } \\
\text { Error } \\
\text { Mean }\end{array}$ \\
\hline $\begin{array}{l}\text { Anaerobic } \\
\text { pretest }\end{array}$ & .0000 & 10 & .40136 & .12692 \\
\hline $\begin{array}{l}\text { Anaerobic } \\
\text { posttest }\end{array}$ & .0000 & 10 & .48520 & .15343 \\
\hline
\end{tabular}

From the table above, it can be seen that the average pretest score is $0.00=$ post-test 0.00 , which means that there is the difference in the average of the exercise results between pretest and post-test. To prove whether the difference is really significant (significant) or not, we need to interpret the results of the paired sample T test contained in the Paired Sample Test output table.

TABLE VII. PAIRED SAMPLES CORRELATIONS OF EXPERIMENTAL GROUP WITH INTERVAL TRAINING METHOD FOR THE IMPROVEMENT OF ANAEROBIC ABILITY

\begin{tabular}{|l|l|l|l|}
\hline & $\mathbf{N}$ & Correlation & Sig. \\
\hline Anaerboic pretest and posttest & 10 & .587 & .075 \\
\hline
\end{tabular}

The correlation coefficient value is 0.587 with a significance value is 0.075 . Looking at the value of Sig. $0.075>$ probability 0.05 , it can be said that there is no relationship between the pre-test and the post-test variables.

\begin{tabular}{|c|c|c|c|c|c|c|c|c|}
\hline & \multicolumn{5}{|c|}{ Paired Differences } & \multirow[t]{3}{*}{$\mathbf{T}$} & \multirow{3}{*}{$\begin{array}{l}\text { d } \\
\text { f }\end{array}$} & \multirow{3}{*}{$\begin{array}{l}\text { Sig } \\
\dot{(2-} \\
\text { tail } \\
\text { ed) }\end{array}$} \\
\hline & \multirow[t]{2}{*}{$\begin{array}{c}\text { Me } \\
\text { an }\end{array}$} & \multirow[t]{2}{*}{$\begin{array}{l}\text { Std. } \\
\text { Devia } \\
\text { tion }\end{array}$} & \multirow[t]{2}{*}{$\begin{array}{c}\text { Std. } \\
\text { Err } \\
\text { or } \\
\text { Me } \\
\text { an }\end{array}$} & \multicolumn{2}{|c|}{$\begin{array}{c}95 \% \\
\text { Confidence } \\
\text { Interval of } \\
\text { the } \\
\text { Difference } \\
\end{array}$} & & & \\
\hline & & & & $\begin{array}{l}\text { Lo } \\
\text { wer }\end{array}$ & $\begin{array}{l}\text { Up } \\
\text { per }\end{array}$ & & & \\
\hline $\begin{array}{l}\text { Pretest } \\
\text { Anaerobic- } \\
\text { Posttest } \\
\text { Anaerobic }\end{array}$ & $\begin{array}{l}.00 \\
000\end{array}$ & $\begin{array}{l}.4099 \\
0\end{array}$ & $\begin{array}{l}.12 \\
962\end{array}$ & $\begin{array}{l}- \\
.29 \\
323\end{array}$ & $\begin{array}{l}.293 \\
23\end{array}$ & $\begin{array}{l}. \\
0 \\
0 \\
0\end{array}$ & 9 & $\begin{array}{l}1,0 \\
00\end{array}$ \\
\hline
\end{tabular}

Based on the Paired Samples Test above table, the Sig value (2-tailed) is $1.00>0.05$, then $\mathrm{HO}$ is accepted and $\mathrm{Ha}$ is rejected. Therefore, it can be concluded that there is no difference in the average between pre-test and post-test. It means that there is no effect of interval training method with resistance band ladder drills training patterns in increasing the anaerobic ability of female futsal players.

TABLE IX. ONE SAMPLE KOLMOGOROV-SMIRNOV TEST OF CONTROL GROUP WITH PYRAMID TRAINING METHOD FOR THE IMPROVEMENT OF

\begin{tabular}{|c|c|c|}
\hline & & Gain \\
\hline \multicolumn{2}{|c|}{$\mathbf{N}$} & 10 \\
\hline \multirow[t]{2}{*}{ Normal Parameters $^{\mathrm{a}}$} & Mean & .1300 \\
\hline & Std. Deviation & 2.06508 \\
\hline \multirow{3}{*}{$\begin{array}{l}\text { Most Extreme } \\
\text { Differences }\end{array}$} & Absolute & .169 \\
\hline & Positive & .169 \\
\hline & Negative & -.118 \\
\hline \multicolumn{2}{|c|}{ Kolmogorov-Smirnov Z } & .535 \\
\hline \multicolumn{2}{|c|}{ Asymp. Sig. (2-tailed) } & .937 \\
\hline
\end{tabular}

Thus, the requirements or assumptions of normality in the use of paired sample $\mathrm{T}$ test have been fulfilled.

TABLE X. PAIRED SAMPlES STATISTICS OF CONTROL GROUP With PyRAMID TRAINING METHOD For THE IMPROVEMENT OF AEROBIC ABILITY

\begin{tabular}{|l|l|l|l|l|}
\hline & Mean & N & $\begin{array}{c}\text { Std. } \\
\text { Deviation }\end{array}$ & $\begin{array}{c}\text { Std. Error } \\
\text { Mean }\end{array}$ \\
\hline Pretest_Aerobic & 36.8200 & 10 & 2.93364 & .92770 \\
\hline Posttest_Aerobic & 36.9500 & 10 & 2.11148 & .66771 \\
\hline
\end{tabular}

From the table above, it can be seen that the average pretest score is 36.82 <post-test 36.95 , which means that there is the difference in the average of the exercise results between pre-test and post-test. To prove whether the difference is really real (significance) or not, we need to interpret the results of the paired sample $\mathrm{T}$ test contained in the Paired Sample Test output table. AEROBIC ABILITY 
test and post-test. To prove whether the difference is really significant (significant) or not, we need to interpret the results of the paired sample T test contained in the Paired Sample Test output table.

TABLE XV. PAIRED SAMPLES CORRELATIONS OF CONTROL GROUP WiTH PYRAMID TRAINING METHOD FOR THE IMPROVEMENT OF ANAEROBIC significance value is 0.021 . Looking at the value of Sig. 0.021 <probability 0.05 , it can be said that there is a relationship between the pre-test and the post-test variables.

TABLE XII. PAIRED SAMPLES TEST OF CONTROL GROUP WITH PYRAMID TRAINING METHOD FOR THE IMPROVEMENT OF AEROBIC ABILITY

\begin{tabular}{|c|c|c|c|c|c|c|c|c|}
\hline & \multicolumn{5}{|c|}{ Paired Differences } & \multirow[t]{3}{*}{$\mathbf{T}$} & \multirow{3}{*}{$\begin{array}{l}\text { d } \\
\text { f }\end{array}$} & \multirow{3}{*}{$\begin{array}{l}\text { Sig. } \\
(2- \\
\text { taile } \\
\text { d) }\end{array}$} \\
\hline & \multirow[t]{2}{*}{$\begin{array}{l}\text { Me } \\
\text { an }\end{array}$} & \multirow[t]{2}{*}{$\begin{array}{c}\text { Std. } \\
\text { Deviati } \\
\text { on }\end{array}$} & \multirow{2}{*}{$\begin{array}{c}\text { Std. } \\
\text { Erro } \\
\mathbf{r} \\
\text { Mea } \\
\mathbf{n}\end{array}$} & \multicolumn{2}{|c|}{$\begin{array}{c}95 \% \\
\text { Confidence } \\
\text { Interval of the } \\
\text { Difference }\end{array}$} & & & \\
\hline & & & & $\begin{array}{c}\text { Lowe } \\
\mathbf{r}\end{array}$ & $\begin{array}{c}\text { Uppe } \\
\mathbf{r}\end{array}$ & & & \\
\hline $\begin{array}{l}\text { Pretest } \\
\text { _Aerobik } \\
\text { Posttest_Aerob } \\
\text { ik }\end{array}$ & $\begin{array}{l}- \\
.130 \\
00\end{array}$ & $\begin{array}{l}.65304 \\
- \\
1.6072 \\
7 \\
1.3472 \\
7\end{array}$ & & & $\begin{array}{l}2.065 \\
08\end{array}$ & $\begin{array}{l}- \\
.1 \\
9 \\
9\end{array}$ & 9 & .847 \\
\hline
\end{tabular}

Based on the Paired Samples Test table above, the of Sig. value (2-tailed) is $0.847>0.05$, then $\mathrm{HO}$ is accepted and $\mathrm{Ha}$ is rejected. Therefore, it can be concluded that there is no average difference between pre-test and post-test. It means that there is no effect of the pyramid training method with resistance band ladder drills training patterns in increasing the aerobic ability of female futsal players.

TABLE XIII. ONE SAMPLE KOLMOGOROV-SMIRNOV TEST OF CONTROL GROUP WITH PYRAMID TRAINING METHOD FOR THE IMPROVEMENT OF ANAEROBIC ABILITY

\begin{tabular}{|c|c|l|}
\hline \multicolumn{2}{|c|}{$\mathbf{N}$} & Difference \\
\hline \multirow{2}{*}{ Normal Parameters $^{\mathbf{a}}$} & \multicolumn{1}{|c|}{ Mean } & 10 \\
\cline { 2 - 3 } & Std. Deviation & .0000 \\
\hline \multirow{2}{*}{ Most Extreme Differences } & Absolute & .23512 \\
\cline { 2 - 3 } & Positive & .132 \\
\cline { 2 - 3 } & Negative & .132 \\
\cline { 2 - 3 } & .110 \\
\hline \multicolumn{2}{|c|}{ Test distribution is Normal. } \\
\hline \multicolumn{2}{|c}{ Kolmogorov-Smirnov Z } & .995 \\
\hline \multicolumn{2}{|c|}{ Asymp. Sig. (2-tailed) }
\end{tabular}

Thus, the requirements or assumptions of normality in the use of paired sample $\mathrm{T}$ test tests have been fulfilled.

TABLE XIV. PAIRED SAMPLES STATISTICS OF CONTROL GROUP With PYRAMID TRAINING METHOD FOR THE IMPROVEMENT OF ANAEROBIC ABILITY

\begin{tabular}{|l|l|l|l|l|}
\hline & Mean & N & $\begin{array}{c}\text { Std. } \\
\text { Deviation }\end{array}$ & $\begin{array}{c}\text { Std. Error } \\
\text { Mean }\end{array}$ \\
\hline Pretest_Anaerobic & .0000 & 10 & .39061 & .12352 \\
\hline Posttest_Anaerobic & .0000 & 10 & .30414 & .09618 \\
\hline
\end{tabular}

From the table above, it can be seen that the average value of pre-test $0,00=$ post-test 0.00 , which means that there is no difference in the average of the exercise between results preABILITY

\begin{tabular}{|c|c|c|c|}
\hline & $\mathbf{N}$ & Correlation & Sig. \\
\hline $\begin{array}{ll}\text { Pretest_Anaerobic } & \& \\
\text { Posttest_Anaerobic } & \end{array}$ & 10 & .799 & .006 \\
\hline
\end{tabular}

The correlation coefficient value is 0.799 with a significance value is 0.006 . Looking at the value of Sig. 0.006 <probability 0.05 , it can be said that there is a relationship between the pre-test and the post-test variables.

TABLE XVI. PAIRED SAMPLES Test OF CONTROL GROUP WiTH PyRAMID TRAINING METHOD FOR THE IMPROVEMENT OF ANAEROBIC ABILITY

\begin{tabular}{|c|c|c|c|c|c|c|c|c|}
\hline & \multicolumn{5}{|c|}{ Paired Differences } & \multirow[t]{3}{*}{$\mathbf{t}$} & \multirow{3}{*}{$\begin{array}{l}\text { d } \\
\text { f }\end{array}$} & \multirow{3}{*}{$\begin{array}{l}\text { Sig. } \\
(2- \\
\text { tail } \\
\text { ed) }\end{array}$} \\
\hline & \multirow[t]{2}{*}{$\begin{array}{c}\text { Mea } \\
\mathbf{n}\end{array}$} & \multirow[t]{2}{*}{$\begin{array}{c}\text { Std. } \\
\text { Deviati } \\
\text { on }\end{array}$} & \multirow[t]{2}{*}{$\begin{array}{c}\text { Std. } \\
\text { Err } \\
\text { or } \\
\text { Mea } \\
\text { n }\end{array}$} & \multicolumn{2}{|c|}{$\begin{array}{c}95 \% \\
\text { Confidence } \\
\text { Interval of } \\
\text { the } \\
\text { Difference } \\
\end{array}$} & & & \\
\hline & & & & $\begin{array}{c}\text { Low } \\
\text { er }\end{array}$ & $\begin{array}{c}\text { Upp } \\
\text { er }\end{array}$ & & & \\
\hline $\begin{array}{l}\text { PretestAnaerobic } \\
- \\
\text { Posttest_Anaero } \\
\text { bic }\end{array}$ & $\begin{array}{l}.000 \\
00\end{array}$ & .23512 & $\begin{array}{l}.074 \\
35\end{array}$ & $\begin{array}{l}- \\
.168 \\
20\end{array}$ & $\begin{array}{l}.168 \\
20\end{array}$ & $\begin{array}{l}.0 \\
0 \\
0\end{array}$ & 9 & $\begin{array}{l}1,0 \\
00\end{array}$ \\
\hline
\end{tabular}

Based on the Paired Samples Test table above, the Sig value (2-tailed) is 1.00>0.05, then $\mathrm{H} 0$ is accepted and $\mathrm{Ha}$ is rejected. Therefore, it can be concluded that there is no average difference between pre-test and post-test. It means that there is no effect of the pyramid training method with resistance band ladder drills training patterns in increasing the anaerobic ability of female futsal players.

\section{DISCUSSION}

After seeing several physical components that are influenced by interval training and pyramid training methods to improve the physiological abilities of female futsal players, the findings below will be explained, which can be discussed further. 
TABLE XVII. TESTS SIGNIFICANCE OF EACH PHYSICAL COMPONENT

\begin{tabular}{|c|c|c|c|c|c|c|}
\hline \multirow[t]{2}{*}{$\begin{array}{l}\text { Componen } \\
\text { ts of }\end{array}$} & \multicolumn{3}{|c|}{ The Interval } & \multicolumn{3}{|c|}{$\begin{array}{l}\text { Method of Pyramid } \\
\text { Training Method of }\end{array}$} \\
\hline & Results & $\begin{array}{c}\text { Sig } \\
\text { n. }\end{array}$ & $\begin{array}{c}\text { Signific } \\
\text { ance } \\
\text { Test of }\end{array}$ & Results & $\begin{array}{c}\text { Sig } \\
\text { n. }\end{array}$ & $\begin{array}{c}\text { Signific } \\
\text { ance } \\
\text { Tests }\end{array}$ \\
\hline Aerobic & $\begin{array}{l}\text { Ascend } \\
\text { ing }\end{array}$ & $\begin{array}{l}0,0 \\
41\end{array}$ & $\begin{array}{l}\text { Significa } \\
\mathrm{nt}\end{array}$ & Increase & $\begin{array}{l}0.8 \\
47\end{array}$ & $\begin{array}{l}\text { Not } \\
\text { Significa } \\
\text { nt }\end{array}$ \\
\hline Anaerobic & $\begin{array}{l}\text { Ascend } \\
\text { ing }\end{array}$ & $\begin{array}{l}1,0 \\
00\end{array}$ & $\begin{array}{l}\text { No } \\
\text { Significa } \\
\text { nt }\end{array}$ & Increase & $\begin{array}{l}1,0 \\
00\end{array}$ & $\begin{array}{l}\text { No } \\
\text { Significa } \\
\text { nt }\end{array}$ \\
\hline Speed & $\begin{array}{l}\text { Increas } \\
\mathrm{e}\end{array}$ & $\begin{array}{l}0,0 \\
03\end{array}$ & $\begin{array}{l}\text { Significa } \\
\mathrm{nt}\end{array}$ & Increase & $\begin{array}{l}0,0 \\
04\end{array}$ & $\begin{array}{l}\text { Significa } \\
\mathrm{nt}\end{array}$ \\
\hline Power & $\begin{array}{l}\text { Increas } \\
\mathrm{e}\end{array}$ & $\begin{array}{l}0.4 \\
65\end{array}$ & $\begin{array}{l}\text { Not } \\
\text { Significa } \\
\text { nt }\end{array}$ & Increase & $\begin{array}{l}0.5 \\
76\end{array}$ & $\begin{array}{l}\text { Not } \\
\text { Significa } \\
\text { nt }\end{array}$ \\
\hline Agility & $\begin{array}{l}\text { Ascend } \\
\text { ing }\end{array}$ & $\begin{array}{l}0,0 \\
33\end{array}$ & $\begin{array}{l}\text { Significa } \\
\text { nt }\end{array}$ & Increase & $\begin{array}{l}0,0 \\
45\end{array}$ & $\begin{array}{l}\text { Significa } \\
\mathrm{nt}\end{array}$ \\
\hline $\begin{array}{l}\text { Speed } \\
\text { Endurance }\end{array}$ & $\begin{array}{l}\text { Ascend } \\
\text { ing }\end{array}$ & $\begin{array}{l}0.7 \\
40\end{array}$ & $\begin{array}{l}\text { Not } \\
\text { Significa } \\
\text { nt }\end{array}$ & Increase & $\begin{array}{l}0,8 \\
77\end{array}$ & $\begin{array}{l}\text { Not } \\
\text { Significa } \\
\text { nt }\end{array}$ \\
\hline $\begin{array}{l}\text { Agility } \\
\text { Endurance }\end{array}$ & $\begin{array}{l}\text { Increas } \\
\text { es }\end{array}$ & $\begin{array}{l}0.0 \\
60\end{array}$ & $\begin{array}{l}\text { Not } \\
\text { Significa } \\
\text { nt }\end{array}$ & $\begin{array}{l}\text { Increase } \\
\mathrm{s}\end{array}$ & $\begin{array}{l}0.0 \\
65\end{array}$ & $\begin{array}{l}\text { Not } \\
\text { Significa } \\
\text { nt }\end{array}$ \\
\hline $\begin{array}{l}\text { Power } \\
\text { Endurance }\end{array}$ & $\begin{array}{l}\text { Increas } \\
\text { es }\end{array}$ & $\begin{array}{l}0.1 \\
21\end{array}$ & $\begin{array}{l}\text { Not } \\
\text { Significa } \\
\text { ntly }\end{array}$ & $\begin{array}{l}\text { Increase } \\
\mathrm{s}\end{array}$ & $\begin{array}{l}0.1 \\
45\end{array}$ & $\begin{array}{l}\text { Not } \\
\text { Significa } \\
\text { ntly }\end{array}$ \\
\hline
\end{tabular}

Through the results that can be seen from the table above, the exercises must consider the principle of specifications if we want the effective increase besides the application of individual principles. Another factor that influences the results is to consider the volume of the exercise which cannot be compared when there are two different methods because each exercise method has the character needs of the amount of volume that can provide physiological body adaptation effects. This is partially proven that an increase in change occurs, but becomes insignificant if it is based on statistical calculations. In the actual implementation, changes in ability to make fast movements will be very significant even if it only takes place in a minimal amount of density. However, if it has an impact in the game or in the performance of the athlete, the results of the match will be decisive for success.

This is a finding that needs to be discussed so that the scientific development in the application of (physical) training methods becomes more meaningful and useful, not just applying those methods. More than that, the coaches are required to be clever in choosing methods and be smart in calculating the intensity and the volume of training needed and are required to get the maximum results in the effort of minimal effort

\section{CONCLUSIONS}

The implications of the research indicate that in physical training, the training method must adapt to the various elements of the physical component to be trained in accordance with the principles and norms of training in physiological and pedagogical laws in order to obtain the maximum meaningful impact of training.
It can be concluded that the application of interval training method with resistance band ladder drill training patterns has an impact in increasing aerobic ability. While for anaerobic, it does not have a significant impact because only a few physical components are categorized as anaerobic that gives an impact. This can be caused by several factors. Therefore, each coach is expected to be able to design an exercise program with interval training method using varied forms of training because this is important so that the training needs become more secure and the training targets are directed. Then, calculate the volume and intensity that are adequate in accordance with the needs of the physical components to be trained. Neither with the pyramid training method, it does not have a significant effect or impact in increasing the dynamic ability of aerobics and aerobics. This is due to the natural characteristics of the pyramid training method, namely the uphill intensity then decreases, resting varies and increases between reps and between sets, as well as the changing distance of each repetition and set. Adequate application of training by paying attention to training methods, training patterns, principles, and norms of training properly are the important keys in getting the overcompensated (Exercise Effects).

For further research, the researchers suggest the need for scientific development in coaching that is more effective and efficient so this research can be developed through other forms of exercise or application to sports that are more specifically dominant physical abilities, such as sports that are dominant in speed (sport speed), dominant power endurance (sport power), or dominant endurance (sport endurance).

\section{REFERENCES}

[1] Wikipedia, Southeast Asian Games, Wikipedia, 2017, retrieved from https://en.wikipedia.org/wiki/Southeast_Asian_Games.

[2] D. Baker and S. Nance, "The Relationship Between Running Speed and Measures of Strength and Power in Professional Rugby League Players," vol. 13(3), pp. 230-235, 1999.

[3] M. Leveritt, P.J. Abernethy, B.K. Barry and P.A. Logan, "Concurrent Strength and A Review," vol. 28(6), pp. 413-427, 1999.

[4] C. Castagna, S.D. Ottavio, J. Granda and B. Alvarez, "Match demands of professional Futsal: A case study," vol. 12, pp. 490-494, 2009.

[5] Ecpljbm Baroni, "Aerobic capacity of male professional futsal players," J. Sports Med. Phys. Fitness, vol. 50, pp. 395-399, September 2014

[6] R. Ramírez-campillo et al., "Effects of plyometric training on maximalintensity exercise and endurance in male and female soccer players," July 2015.

[7] M. Karahan, "The Effect of Skill-Based Maximum Intensity Interval Training on Aerobic and Anaerobic Performance of Female Futsal Players," pp. 223-227, 2012.

[8] CCAE Castellini, "Vertical Jump Performance in Italian Male and Female National Team Soccer Players," J. Strength Cond. Res, vol. 4(27), pp. 1156-1161, 2013.

[9] N. Makaje, R. Ruangthai, A. Arkarapanthu and P. Yoopat, "Physiological demands and activity profiles during futsal match play according to competitive level," J Sport. MED PHYS Fit, vol. 52, pp. 366-74, 2012

[10] G.P. Millet and B.C. Guinhouya, "Relationship between oxygen uptake kinetics and performance in repeated running sprints," May 2014.

[11] P. Krustrup, M. Mohr, H. Ellingsgaard and J. Bangsbo, Physical Demands during an Elite Female Soccer Game: Importance of Training Status ABSTRACT.

[12] R.P. and P.O. Jonathan Bloomfiels , "Physical demands of different 
932, 2006

positions in FA Premier League soccer," J. Sport. Sci Med, vol. 6, pp. 63-70, 2007.

[13] S.E. Mcinnes, "The physiological load imposed on basketball players during competition The physiological load imposed on basketball players during competition," pp. 37-41, August 2013.

[14] M.J.L. Alexander and S.L. Boreskie, "characteristics of handball analysis," pp. 76-82.

[15] A.A.J.M. Sera, N. Dogramaci Mark, L. Watsford, "Time-Motion Analysis Of International And National Futsal Levels," J. of Strength Cond. Res, vol. 3(25), pp. 646-651, 2011.

[16] C. Ion, "The futsal players' physical training during the special training period," vol. 12(2), pp. 125-132, 2011.

[17] G. Ziv, "Physical Attributes, Physiological Characteristics, On-Court Performances and Nutritional Strategies of Female and Male Basketball Players," August 2009.

[18] L. Ricotti, "Static and dynamic balance in young athletes," 2011.

[19] J.M. Sheppard and W.B. Young, "Agility literature review: Classifications, training and testing," J. Sports Sci, vol. 24(9), pp. 919-
[20] F.S. Hadi, E. Hariyanto and F. Amiq, "Pengaruh Latihan Ladder Drills Terhadap Peningkatan Kelincahan Siswa U-17 Di Persatuan,” 2004.

[21] I.K.H. Kusuma, K.C.A. dan Kardiawan, "Pengaruh Pelatihan Ladder Drill Terhadap Kecepatan Dan Kelincahan," Semin. Nas. Ris. Inov, pp. 16-20, 2017.

[22] N.E. Fraenkel, J.R. Wellen, How to Design and Evaluate Research in Education. 2nd ed., United States of America: Mc-Graw Hill, inc., 1993.

[23] L.A. Leger and J. Lambert, "Applied Physiology to Predict VO2 max *," Eur. J. Appl. Physiol, vol. 49, pp. 1-12, 1982.

[24] B. Mackeinze, 101 Performance Evaluation Tests. London: Electric Word Plc, 2005.

[25] M. Williams, A. Squillante, and J. Dawes, "The Single Leg Triple Hop for Distance Test," Strength Cond. J, vol. 39(3), pp. 94-98, 2017.

[26] K.L. Homsi and D.H. Annis, "US 2010/0129780 A1: Athletic performance rating system,” Pat. Appl. Publ, vol. 1(19), 2009. 